\title{
Infodemik Covid-19 dalam Perspektif Jean Baudillard (Studi Kasus Berita Hoaks Covid-19 di Website covid19.go.id)
}

\author{
Ignasius Liliek Senaharjanta ${ }^{1}$, Shella Fendista ${ }^{2}$ \\ 1,2 Universitas Bunda Mulia \\ E-mail : isenaharjanta@bundamulia, Shellafendista@gmail.com
}

\begin{abstract}
Cara Sitasi: Iganisius LS, Shella F (2021) Infodemik Covid-19 dalam Perspektif Jean Baudillard (Studi Kasus Berita Hoaks Covid-19 di Website covid19.go.id), 2021 21(2), 97-107 Retrieved from https://doi.org/10.31294/jc.v19i2
\end{abstract}

\begin{abstract}
The development of Information Technology which has impacts on the ease of producing and accessing information has caused the rapid circulation of information in the community. However, the circulation of this information does not completely contain the truth. Hoax information is intentionally produced and spread to the public through various application platforms aimed to distorting the facts so that the information is believed to be the real truth. This condition can be seen from the ease people share the information they receive through their smart devices to a number of people closest to them or to groups or community wherr they participate in. This research is a descriptive qualitative research. The data in this study was carried out by analyzing hoax news mapping data collected by the covid-19 handling task force through the covid19.go.id website obtained through the Indonesian Anti-Defamation Society (Mafindo). The news data and hoax information in the form of verbal and visual were analyzed with a qualitative content analysis approach to analyze how the hoax phenomenon during this pandemic was deliberately created and spread by the public.Furthermore, the results of the analysis are examined with the perspective of Jean Baudillard's simulacra and hyperreality. The result shows that information as the main product of the information society is no longer dominated by information producers such as television and newspapers, but now anyone who has a device and is connected to the internet can produce information. The impact of this is that humans are trapped in false reality and dwell on duplication and superficiality.
\end{abstract}

Keyword: information technology, hoax covid-19, simulacrum jean baudillard

\section{PENDAHULUAN}

Perkembangan informasi digital di era masyarakat informasi menunjukkan peningkatan yang signifikan. Peningkatan tersebut terjadi akibat terjadinya perubahan perilaku masyarakat dalam memproduksi dan mengakses informasi yang beredar. Perubahan ditengah masyarakat tersebut tidak lain dipicu oleh perkembangan teknologi informasi yang sangat cepat. Pada era sebelumnya, masyarakat mengandalkan media-media tradisional seperti surat kabar dan media penyiaran sebagai sumber utama untuk memenuhi kebutuhan informasi. Namun, saat ini di era informasi, masyarakat beralih memanfaatkan media baru yang terkoneksi dengan internet untuk mendapatkan informasi secara lebih real time dan cepat. Bahkan, perkembangan teknologi informasi memberikan kesempatan bagi siapa pun yang memiliki koneksi internet untuk memproduksi informasi.

Jumlah pengguna internet di Indonesia sendiri pada Februari 2020 sebesar 175,3 juta atau sekitar 64 persen dari total jumlah penduduk di Indonesia. Berdasarkan data tersebut, 171 juta atau sekitar 98 persen dari pengguna internet di Indonesia tercatat menggunakan gawai pintar untuk melakukan akses internet. Sedangkan, media sosial berbagi video Youtube dan aplikasi chatting Whatsapp menjadi aplikasi yang paling banyak diakses dengan presentasi persentasi mencapai 88 persen dan 84 persen.
Sementara itu, berdasarkan data diatas rata-rata masyarakat Indonesia melakukan akses di Internet selama 7 jam 59 menit. (katadata.co.id).

Besarnya jumlah pengguna internet tersebut tentunya sangat berpengaruh pada peredaran informasi di tanah air. Hal tersebut disebabkan karena setiap pengguna yang memiliki koneksi internet dapat diasumsikan memiliki "media komunikasi" sendiri dan dapat memproduksi konten berdasarkan orientasi masing-masing. Bahkan, perilaku tersebut tidak sebatas dilakukan pengguna oleh individu saja, tetapi lembaga dan institusi baik formal dan non-formal melakukan hal yang sama, yaitu memproduksi informasi. Kebebasan berekspresi dalam memproduksi dan mengakses informasi ini berdampak pada maraknya informasi yang beredar di dunia maya. Menurut Wahyuni (2020:38-39), kebebasan berekspresi dalam memproduksi dan mengakses informasi terkait dengan teknologi informasi dan komunikasi ini dapat ditinjau dari dua sisi, Pertama, dari sisi optimis perkembangan teknologi ini dapat dimaknai sebagai kemudahan bagi para penggunanya dalam mengoptimalkan akses informasi. Misalnya, akses informasi yang berasal dari pemerintah, maka masyarakat dapat turut serta berkontribusi dan mempangaruhi dalam pengambilan kebijakan yang dilakukan oleh pemerintah. Sehingga, hal tersebut dapat membantu situasi yang demokratis dalam pengambilan keputusan. 
Sedangkan, dari sisi pesimis perkembangan teknologi informasi dan komunikasi semakin mengukuhkan dominasi dari para penguasa atau pemilik modal melalui teknologi. Selain itu, kebebasan ekspresi untuk memproduksi informasi memiliki juga dampak negatif yaitu maraknya penyebaran informasi hoaks. Hoaks sendiri mengacu pada informasi palsu atau bohong yang muncul melalui internet dan memiliki tujuan tertentu seperti membuat kepanikan atau ketakutan massal. Informasi atau kabar palsu ini diproduksi oleh oleh oknum yang tidak bertanggung jawab (liputan6.com).

Penyebaran informasi atau berita bohong yang marak di media sosial ini tidak mengenal waktu, namun penyebarannya cenderung meningkat pada momen-momen tertentu atau ketika ada isu penting yang mendapatkan perhatian masyarakat dan menyangkut kepentingan nasional. Isu-isu tersebut misalnya seperti pilkada, pilpres, bencana alam, maupun kondisi krisis lainnya. Dalam konteks politik, hoaks digunakan sebagai propaganda yang memiliki tujuan untuk mempengaruhi opini pemilih dan membuat citra dari politisi positif atau negatif. Hoaks dalam politik juga kerap dimanfaatkan untuk membuat citra pemerintah buruk terutama terkait dengan kebijakan-kebijakan strategis.

Penyebaran berita bohong dalam masyarakat tidak terbatas pada konteks politik, namun juga menyasar isu kesehatan seperti pada masa pandemik virus Covid-19. Dalam kurun waktu Agustus 2018 hingga April 2019, hoaks terkait dengan isu kesehatan menempati urutan ketiga, setelah politik menempati posisi pertama, dan isu pemerintah yang menempati posisi kedua (health.grid.id). Gugus Tugas Percepatan Penanganan Covid-19 (GTTPC19) per Juni 2020 mencatat sedikitnya terdapat 137.829 kasus hoaks terkait pandemik covid-19 yang berhasil diidentifikasi. Dari jumlah tersebut, sebanyak 130.680 kasus saat ini telah dilakukan penyelidikan oleh Satuan Siber Polri. Pihak Kepolisian pun berhasil menahan 17 tersangka dan 87 orang masih dalam proses.

Berdasarkan informasi yang dihimpun oleh Kementerian Komunikasi dan Informasi, penyebaran hoaks pada masa pandemik Covid-19 diantaranya terkait dengan informasi yang berkisar pada isu penyebaran, penanganan serta data informasi terkait dengan jumlah pasien positif Covid-19. Beberapa hoaks yang pernah beredar dimasyarakat memuat tentang melonjaknya jumlah pasien secara tidak wajar di beberapa rumah sakit nasional, bentuk-bentuk penyebaran atau penularan Covid-19 atau propinsi tertentu yang hampir disetiap daerahnya berstatus zona merah dan hitam. Isu hoaks yang beredar mengenai penanganan
Covid-19 antara lain berkutat pada kebijakankebijakan strategis yang diputuskan pemerintah untuk menangani pandemik Covid-19. Sedangkan, terkait dengan data pasien terinfeksi virus corona akibat penyebaran hoaks, isu yang beredar adalah data pasien meninggal yang diberikan oleh pemerintah bukan data yang sebenarnya.

Penyebaran berita bohong atau hoaks ini banyak memanfaatkan jaringan yang terdapat pada media sosial. Berdasarkan data yang dirilis tahun 2019 oleh CIGI- "Ipsos Global Survey on Internet and Security Trust”, masyarakat dunia menyatakan bahwa media sosial Facebook merupakan media sosial dengan tingkat penyebaran hoaks terbesar. Platform media sosial lainnya, seperti Twitter, Instagram dan lainnya menempati posisi setelah Facebook (katadata.co.id). Selain itu, berita hoaks juga beredar deras di aplikasi chating seperti WhatsApp. Bentuk berita hoaks tidak saja diproduksi dalam bentuk teks, tetapi juga ditampilkan dalam bentuk gabungan antara teks, foto maupun audio visual. Bahkan, tidak jarang visual baik berupa foto maupun video yang digunakan sebagai pendamping berita merupakan kejadian yang sama sekali tidak ada hubungannya dengan informasi yang diberitakan.

Berbagai informasi hoaks dalam bentuk artikel berita maupun bentuk informasi yang lain ini mengarah pada infodemik atau peredaran informasi dalam jumlah yang sangat massif. Banyaknya informasi yang beredar dan diterima secara langsung oleh masyarakat melalui aplikasi yang terdapat digawai menyebabkan sejumlah dampak negatif, diantaranya memicu kepanikan ditengah publik, masyarakat kesulitan untuk membedakan informasi yang benar dan informasi hoaks. Selain itu, menurut para ahli dari sisi individu, penyebaran informasi hoaks dapat menyebabkan depresi dan perasaan marah, curiga, cemas, bahkan dapat mendistorsi pikiran sehat (health.grid.id).

Pada masa kondisi kritis pandemik covid-19, masyarakat juga dihadapkan pada kondisi yang serba tidak menentu. Derasnya aliran informasi covid-19 merupakan salah satu kondisi yang menambah ketidakpastian di masa pandemik covid19. Berbagai informasi dalam jumlah yang sangat besar "mengepung" masyarakat sehingga menyebabkan masyarakat kesulitan mendapatkan informasi yang benar untuk menghadapi penyebaran virus covid-19. Berdasarkan data yang dirilis oleh Masyarakat Anti Fitnah Indonesia (MAFINDO) informasi hoaks covid-19 menyebar dalam berbagai macam tema, diantaranya yang tertinggi kesehatan atau terkait dengan nutrisi, bencana, agama, etnis dan politik. 
Langkah pencegahan penyebaran hoaks menjadi tanggung jawab berbagai elemen masyarakat. Peran pencegahan yang dapat dilakukan oleh masyarakat adalah dengan melakukan validasi isi berita melalui website-website yang memerangi hoaks seperti turnbackhoax.id, website resmi kominfo.go.id dan website lain serupa yang disediakan oleh media mainstream seperti cekfakta.tempo.id. Selain itu, langkah pencegahan lainnya juga dapat dilakukan dengan melaporkan konten tertentu yang dianggap hoaks ke pengelola media sosial melalui kolom menu report konten. Media sebagai saluran penyampaian informasi juga dapat berperan dalam mencegah penyebaran hoaks. Media dapat melakukan pencerahan dengan melakukan klarifikasi terhadap informasi hoaks yang sudah terlanjur beredar dan viral ditengah masyarakat.

Fenomena infodemik ditengah krisis pandemi covid19 menjadi fokus kajian komunikasi yang menarik. Hal ini disebabkan karena masyarakat saat ini masih mempercayai informasi atau pesan yang diterimanya sebagai sebuah kebenaran. Kondisi ini dapat dilihat dari mudahnya masyarakat dalam membagikan informasi yang diterimanya melalui gawai pintar yang dimilikinya ke sejumlah orang terdekat maupun ke grup atau kelompok komunitas yang

\section{Infodemik Covid 19}

Infodemik merupakan penggabungan dari kata informasi dan epidemik, yang secara harafiah informasi memiliki pengertian sebagai data yang telah diproses sedemikian rupa sehingga meningkatkan pengetahuan seseorang yang menggunakan data tersebut (Kadir, 2002:31); (McFadden, et.al, 1999). Sedangkan, epidemik sendiri merupakan suatu sebaran wabah yang lebih besar dan menyebar dengan sangat cepat, sehingga tindakan untuk pembatasan wabah tersebut tidak dapat dilakukan lagi karena sudah terlambat (theconversation.com). Maka berdasarkan pengertian diatas, infodemik merupakan suatu informasi yang berlaku seperti wabah, dimana informasi tersebut telah sengaja diproduksi oleh seorang individu, kelompok atau institusi tertentu, entah bersifat benar atau pun salah, menyebar secara meluas hingga tidak dapat dikontrol lagi.

Infodemik bisa dikatakan sebagai tsunami informasi. Hal ini mengacu pada gelombang informasi yang besar terhadap suatu masalah baik secara offline maupun online, sehingga kemunculannya justru dapat mengganggu usaha pencarian solusi terhadap masalah yang dihadapi tersebut (kominfo.go.id). Informasi melimpah tersebut tentunya diproduksi dan disebarkan dengan atau tanpa sengaja oleh individu, kelompok atau instansi yang pastinya memiliki tujuan tertentu. Informasi tersebut cenderung mengakibatkan kepanikan, keresahan, bias informasi, kemarahan bagi publik yang menerima informasi tersebut. diikutinya. Padahal disatu sisi kebenaran dari informasi yang diterimanya masih diragukan atau belum diverifikasi kebenarannya.

Perkembangan teknologi informasi yang berdampak pada kemudahan dalam memproduksi dan mengakses informasi, merupakan penyebab maraknya peredaran informasi ditengah masyarakat. Namun demikian, peredaran informasi tersebut tidak seluruhnya mengandung kebenaran. Informasi hoaks sengaja diproduksi dan disebarkan ke tengah masyarakat melalui berbagai platform aplikasi tersebut bertujuan untuk memutarbalikkan fakta sehingga informasi tersebut dipercaya sebagai suatu kebenaran yang sesungguhnya. Dari sisi produsen, penyebaran informasi hoaks memiliki motif sengaja untuk menyesatkan masyarakat (iseng), bercanda dan sebagai bentuk ketidakpuasan terhadap pemerintah. Sedangkan, dari sisi masyarakat merasa bangga dan senang kalau jadi orang yang pertama kali menyebarkan informasi tersebut. Berdasarkan pada latar belakang yang telah dijabarkan diatas, maka penelitian ini ingin mengkaji bagaimana fenomena infodemik yang terjadi di masa pandemik covid-19 melalui perspektif atau pandangan dari Jean Baudillard.

Penyebaran infodemik secara massif didukung oleh perkambangan internet yang sangat pesat. Kemudahan berselancar di internet untuk mendapatkan informasi tertentu justru terkadang berbahaya, mengingat bahwa manusia memiliki kecenderungan untuk selalu ingin mengetahui segala sesuatu yang ada disekitarnya. Perilaku keingintahuan tersebut disebabkan karena manusia selalu up to date, dan mencari informasi untuk mengatasi masalah. Namun, tidak jarang yang didapatkan melalui internet atau media justru informasi yang bersifat simpang siur, disinformasi, misinformasi. Di satu sisi, perkembangan teknologi komunikasi menyebabkan masyarakat saat ini memiliki kebiasaan baru berupa menyebarkan informasi.

Penyebaran informasi tersebut dilakukan karena masyarakat saat ini memiliki kecenderungan untuk selalu ingin menjadi yang pertama dalam menyebarkan informasi didapatkannya melalui internet. Penyebaran informasi yang dilakukan secara cepat tersebut tidak disertai dengan melakukan cek dan ricek terlebih dahulu, sehingga informasi tersebut menyebabkan masyarakat yang menerimanya tidak tahu mana yang benar dan salah. Ditambah lagi, kecenderungan tersebut tidak diikuti dengan budaya literatur, sehingga apa yang diterima langsung ditelan mentah-mentah tanpa melakukan cross check terlebih dahulu. Hal ini tentu akan berdampak buruk untuk kesehatan fisik maupun mental dari public (who.int). 
Lebih lanjut, terkait dengan penjelasan mengenai infodemik diatas, menurut World Health Organization (WHO), terdapat tiga hal utama yang tersebar dalam infodemik:

1. Informasi, merupakan suatu hal yang memang terbukti secara akurat mengenai suatu hal, dalam kasus ini adalah mengenai virus itu sendiri. Misalnya asal muasal virus Covid, bagaimana cara pencegahannya, bagaimana tanda ketika seseorang terkena covid, bagaimana cara mengobatinya. Halhal ini tentu harus berdasarkan dari uji ilmiah resmi, sehingga informasi yang tersebar dapat dipertanggungjawabkan.

2. Misinformasi, merupakan suatu informasi yang salah. Informasi ini dibuat dan disebarkan tanpa disengaja, dan tidak dengan tujuan untuk membahayakan orang lain, namun mereka mempercayai bahwa informasi tersebut benar adanya dan dengan tujuan baik agar orang sekitarnya tahu juga.

3. Disinformasi, dalam kamus KBBI merupakan suatu informasi yang salah, yang sengaja diproduksi baik oleh individu, kelompok, atau suatu institusi, yang memiliki agenda tertentu, dengan tujuan untuk menimbulkan ke bingungan, ke panikan, ke marahan di masyarakat.

Pada perkembangannya masayarakat menganggap infodemik lebih berbahaya dibandingkan virus Covid 19 itu sendiri. Has tersebut disebabkan karena penyebarannya dalam terjadi dengan cepat dan meluas. Penyebaran infodemik memiliki dampak yang besar ditengah masyarakat, seperti pada aspek kehidupan, Kesehatan, ekonomi dan politik. Lebih lanjut, bahaya lain dari infodemik adalah adanya informasi salah yang menggiring opini publik kepada pemahaman tertentu dan dapat mengubah stigma masyarakat, baik mengenai covid 19 dan juga pemerintah.

Berdasarkan pada penelitian The American Society of Tropical Medicine and Hygiene yang dipublikasikan pada 10 Agustus 2020, Indonesia merupakan salah satu negara yang masuk dalam enam negara paling banyak menyebarkan informasi hoax. Informasi tersebut mencakup tentang isu konspirasi mengenai covid 19, vaksin, dan rumorrumor lain. Peredaran hoax tersebut tersebar melalui berbagai platform di media sosial seperti facebook dan twitter. Penyebaran hoaks ini tentunya sangat berdampak terhadap kepercayaan publik kepada pemerintah, sehingga hal tersebut semakin mempersulit pemerintah dalam menangani krisis akibat dari covid-19.

\section{Berita Hoaks}

Kemajuan teknologi komunikasi dan informasi di era digital saat ini sangatlah pesat. Berbagai media bermunculan dan menjadi wadah untuk penyebaran informasi secara cepat, tanpa mengenal ruang dan waktu, tidak ada batasan akan siapa yang akan memproduksi, distribusi, atau mengkonsumsi suatu informasi. Hal ini pun menjadi salah satu aspek pendorong untuk berita hoaks dapat tersebar dengan mudah di internet. Berdasarkan data yang dihimpun oleh Badan Intelijen Negara (BIN), 60\% dari kontenkonten media sosial di Indonesia ternyata didominasi informasi bohong atau hoaks.

Hoaks dalam Bahasa Indonesia memiliki pengertian sebagai berita bohong, informasi palsu, tidak bersumber atau kabar dusta. Sedangkan, definisi yang lain menyebutkan bahwa hoaks memiliki arti olok-olok, cerita bohong, dan memperdayakan alias menipu. Dalam Oxford English dictionary, hoaks disebut juga sebagai 'malicious deception' atau 'kebohongan yang dibuat dengan tujuan jahat'. Menurut Silverman (2015), hoaks merupakan rangkaian informasi yang memang sengaja untuk menyesatkan, tetapi "dijual" sebagai suatu kebenaran. Lebih lanjut, hoaks bukan saja sekadar misleading alias menyesatkan, informasi dalam fake news juga sering kali tidak memiliki landasan faktual, tetapi disajikan seolah-olah sebagai serangkaian fakta. Ahli Komunikasi Universitas Indonesia Profesor Alwi Dahlan menjelaskan "hoaks" atau kabar bohong merupakan kabar yang sudah direncanakan oleh penyebarnya, yang merupakan manipulasi berita yang sengaja dilakukan dan bertujuan untuk memberikan pengakuan atau pemahaman yang salah.

Menurut Ketua Dewan Pers, Yosep Adi Prasetyo bahwa terdapat beberapa ciri-ciri berita hoaks:

1. Mengakibatkan kecemasan, kebencian, dan permusuhan.

2. Sumber berita tidak jelas. Hoaks di media sosial biasanya pemberitaan media yang tidak terverifikasi, tidak berimbang, dan cenderung menyudutkan pihak tertentu.

3. Bermuatan fanatisme atas nama ideologi, judul, dan pengantarnya provokatif, memberikan penghukuman serta menyembunyikan fakta dan data.

4. Adanya HURUF KAPITAL, huruf tebal (bold), banyak tanda seru, dan tanpa menyebutkan sumber informasi. (bulelengkab.go.id)

\section{Covid19.go.id}

Covid19.go.id merupakan situs informasi resmi penanggulangan virus corona, yang dibentuk oleh Gugus Tugas Percepatan Penanganan Covid-19 pada Rabu 18 Maret 2020. Menurut keterangan dari 
Badan Nasional Penanggulangan Bencana (BNPB), situs ini menjadi sumber informasi resmi dari pemerintah, yang dikembangkan oleh Tim Komunikasi Risiko dan Pelibatan Masyarakat untuk Penanggulangan Covid-19, yang bertujuan untuk memberikan informasi seputar virus tersebut, dan juga untuk mengantisipasi informasi yang beredar di masyarakat.

Pemerintah menyadari bahwa masyarakat saat ini membutuhkan informasi yang akurat dan dapat dipertanggungjawabkan. Oleh karena ini Tim Gugus Tugas tim Gugus Tugas yang terdiri dari pihak Pemerintah, Badan PBB (UNICEF, WHO, dan lainnya), mitra pembangunan internasional, organisasi masyarakat sipil dan dunia usaha, membentuk situs resmi covid19.go.id guna memberikan informasi satu pintu yang akurat, seperti data statistik pesebaran virus corona secara real time, penjelasan protokol kesehatan, vaksinasi yang akan dilakukan, langkah yang sedang pemerintah lakukan dalam penanganan covid, juga Hoax Buster yang tersebar dimasyarakat.

Dengan adanya situs resmi ini, pemerintah mengajak masyarakat untuk dapat mematuhi protokol kesehatan yang ada, anjuran pemerintah, serta dapat menjadi sumber informasi utama yang bisa diandalkan oleh masyarakat. (Kompas.com)

\section{Analisis Isi Kualitatif}

Analisis isi kualitatif dalam penelitian ini berdasarkan pada perspektif dari Margrit Schreier (2012), yang menjelaskan bahwa analisis isi kualitatif merupakan salah satu metode analisis alternatif untuk mengetahui isi teks media dengan menjelaskan makna dari data yang telah dimiliki oleh peneliti. Analisis ini dipergunakan untuk melakukan interpretasi terhadap berbagai data yang terdiri dari interview data, tranksip focus group discussion, brosur, website surat kabar, iklan data grafis yang ditampilkan dalam bentuk verbal maupun visual. Interpretasi yang dilakukan pada analisis isi kualitatif merupakan interpretasi dengan pemberian makna berdasarkan pada apa yang didengar, baca dan lihat dari data-data yang dimiliki. Sehingga, proses interpretasi dalam analisis ini merupakan proses menyatukan persepsi tentang latar belakang materi dengan pemahaman atau preferensi dari diri sendiri.

Analisis isi kualitatif memiliki asumsi utama bahwa makna bukanlah sesuatu yang melekat pada suatu teks, namun pemberian makna diberikan secara aktif oleh penerima dalam mengkonstruksi makna tersebut. Dalam pengertian tersebut maka analisis isi kualitatif merupakan metode yang dipergunakan untuk mendeskripsikan materi yang membutuhkan interpretasi yang mendalam. Langkah deskripsi itulah yang menjadi tujuan dari analisis isi kualitatif.
Analisis isi kualitatif dapat diterapkan untuk berbagai macam data penelitian baik yang diolah sendiri maupun data yang didapatkan melalui website, media maupun bentuk rekaman data lainnya. Dalam penerapannya sendiri analisis isi kualitatif merupakan metode yang memiliki tiga fitur penting yaitu sistematis, fleksibel dan reduksi data. Fitur sistematis merupakan hal penting dan utama dalam analisis isi kualitatif, pada fase ini merupakan tahapan untuk melakukan pemeriksaan atau penyesuaian data yang dimiliki dengan pertanyaan penelitian, pemilihan materi pendukung, membangun kerangka yang terbagi menjadi beberapa kategorisasi dan mengubah data-data tersebut menjadi informasi untuk ditafsirkan dan mempresentasikan hasil dari interpretasi yang telah dilakukan.

Selanjutnya, fitur fleksibel dalam analisis isi kualitatif memiliki arti bahwa dalam pelaksanaan penelitian kerangka yang telah disusun telah sesuai dengan materi yang dimiliki. Hal ini dilakukan sebagai bagian untuk menjaga bahwa data yang digunakan valid. Validasi data dianggap valid jika kategorisasi yang dilakukan sejalan dengan konsep dalam pertanyaan penelitian. Fitur yang terakhir adalah reduksi data, dalam hal ini reduksi data dilakukan untuk memfokuskan pada aspek penelitian yang telah dipilih. Langkah untuk melakukan reduksi data ini dilakukan dengan membatasi hanya pada data analisis yang dibutuhkan atau yang relevan dengan pertanyaan penelitian yang dilanjutkan dengan pengklasifikasian secara secara spesifik.

\section{Simulacra dan Hyperrealitas Jean Baudillard}

Konsep mengenai simulacra atau simulacrum diperkenalkan pertama kali oleh Filsuf Prancis yang juga teoritikus sosial-budaya, Jean Baudillard. Simulacra merupakan kelanjutan dari konsep simulasi yang telah dirumuskan lebih dulu oleh Baudillard. Pemikiran ini muncul berlandaskan pada pandangan Baudillard yang melihat bahwa ada jarak yang memisahkan antara budaya dan pemikiran modern dengan postmodern. Oleh sebab itu, melalui simulacra, Baudillard menawarkan paradigma atau cara pandang baru untuk melihat perubahan sosialbudaya yang terjadi secara drastis antara modern dan post-modern.

Simulacra secara umum memiliki pengertian sebagai aksi atau tindakan menirukan dengan maksud untuk menipu. Lebih lanjut, simulacra juga memiliki pengertian sebagai penampilan palsu, kemiripan permukaan, atau tiruan dari sesuatu (Lubis, 2014:180). Baudillard membagi pengertian simulacra tersebut menjadi tiga jenis: pertama, merupakan bentuk pemalsuan yang marak terjadi 
pada era zaman klasik dan pencerahan, kedua, yaitu tindakan yang berkaitan dengan produksi pada masa era industri. Sedangkan, ketiga merupakan tindakan yang terkait dengan kode yang banyak dilakukan oleh masyarakat di era saat ini.

Gambaran mengenai simulacra yang terjadi ditengah masyarakat itu sendiri tampak pada berbagai macam hal yang ditampilkan media, yaitu seperti berbagai macam tayangan program acara televisi yang banyak menampilkan berbagai macam simulasi atau citraan, dan bukan realitas aslinya, pertunjukan taman hiburan Disneyland yang juga banyak menampilkan tiruan kehidupan manusia, hewan maupun membuat tiruan dari berbagai macam habitat alam yang justru tampak lebih baik dan indah dari bentuk aslinya. Menurut Baudillard gambaran ini memperlihatkan bahwa yang asli dan nyata telah mati, dan kemudian hal tersebut digantikan dengan berbagai simulasi (Lubis, 2014:181).

Pandangan mengenai gambaran simulacra yang dikemukakan oleh Baudillard tersebut salah satunya muncul akibat dari perkembangan teknologi dan perkembangan ekonomi yang mengarah pada produksi industri elektronik di dunia virtual. Perkembangan teknologi dan perkembangan ekonomi inilah yang menyebabkan masyarakat saat ini masuk pada abad informasi. Produksi yang dimaksud disini tidak saja berkaitan dengan produksi barang namun juga informasi, makna dan pengetahuan (Edkins, et.al, 2010: 72). Sehingga, pada akhirnya perkembangan industri di dunia virtual yang pesat pada era informasi saat ini menyebabkan peredaran informasi yang beredar ditengah masyarakat sangat berlimpah. Maraknya produksi informasi ini pada akhirnya menyebabkan masyakat menghadapi kesulitan untuk membedakan informasi yang asli dan informasi yang palsu.

Lebih lanjut, Baudillard menyebut perkembangan revolusi informasi tersebut disebut juga dengan "hyperreality". Berbagai macam produksi model, makna dan simbol yang dipengaruhi oleh hyperreality sangat berdampak pada pikiran dan tingkah laku masyarakat. Hal ini terutama dipengaruhi oleh informasi, iklan maupun produkproduk lain yang diproduksi baik oleh berbagai media komunikasi dan informasi serta media hiburan. Gelombang informasi yang besar tersebut mempengaruhi dan memberi kesan yang kuat kepada setiap individu sehingga dampaknya adalah dalam kondisi demikian individu-individu tersebut mulai meninggalkan realitas yang faktual dan masuk ke hyperrealitas melalui perantaraan teknologi.

Menurut Baudillard produksi kode dan simulasi yang didominasi oleh media saat ini merupakan tahapan simulacrum yang berada pada tatanan ketiga. Tatanan pertama yaitu pada masa renaisans sampai pada masa revolusi industri. Tatanan pertama ini masyarakat melakukan peniruan dan pemalsuan dari yang asli. Misalnya dengan melakukan pemalsuan, memoles dan membuat replika. Tatanan kedua, dimulai pada masa era industri yang memiliki produksi utama berupa rangkaian reproduksi murni dan merupakan bentuk objek yang sama. Contoh produksi dari tatanan kedua ini adalah industri mobil, traktor, dan bentuk industri lainnya.

Berbagai gejala yang memperlihatkan bahwa masyarakat saat ini telah terjebak dalam hyperrealitas adalah fenomena-fenomena dimana masyakat saat ini lebih menyukai untuk membentuk dirinya sendiri sebagai realitas citraan. Pembentukan diri sebagai realitas citraan ini dilakukan oleh masyarakat untuk memberikan makna tertentu kepada dirinya melalui berbagai barang-barang yang digunakannya. Hal inilah yang disebut oleh Baudillard bahwa yang real dibuat menjadi tidak nyata oleh "hyperreal" dan simulasi menjadi lebih benar dari kebenaran (Lubis, 2014:185). Pernyataan tersebut sejalan seperti yang diungkapkan oleh Guy Debord bahwa masyarakat saat ini telah menjadi masyarakat konsumsi dan masyarakat tontonan. Masyarakat tontonan merujuk pada pengertian bahwa sebagian besar waktu yang dimiliki oleh masyarakat dihabiskan didepan televisi dan internet. Terpaan media tersebut pada akhirnya mempengaruhi mereka untuk menjadi masyarakat yang konsumtif dan sekaligus berperilaku menjadi masyarakat tontonan (Kaufmann, 2006)

\section{METODE PENELITIAN}

Data kualitatif adalah data yang berbentuk kata-kata, kalimat-kalimat, narasi-narasi. Data pada penelitian ini dilakukan dengan menganalisa terhadap sejumlah data pemetaan konten informasi hoaks covid-19 yang dihimpun oleh website covid19.go.id melalui Mafindo. Kumpulan berbagai data informasi dan berita hoaks yang dianalisis dengan prosedur analisis isi kualitatif tersebut, kemudian dikaji dengan perspektif simulacra dan hiperrealitas dari Jean Baudillard. Prosedur analisa dilakukan dengan menggunakan berbagai referensi yang mendalam dan terkait dengan topik penelitian ini. Pengumpulan data dilakukan dengan mengumpulkan bahan-bahan dokumentasi yang relevan dengan penelitian ini. Data tersebut merupakan kumpulan berbagai informasi dan berita hoaks dihimpun di website covid19.go.id.

Analisis data pada penelitian ini menggunakan pendekatan analisis isi kualitatif. Analisis isi kualitatif merupakan salah satu cara untuk menggali informasi melalui pendekatan berbagai macam bentuk literatur seperti jurnal akademik, penelitian, buku-buku yang relevan dan dokumentasi video maupun foto. Adapun langkah-langkah rencana 
analisis yang akan dilakukan pada penelitian ini sebagai berikut:

1. Peneliti mencari dan menyeleksi data pemetaan informasi hoaks yang terdapat di website covid19.go.id dan dihimpun oleh Mafindo. Pada tahapan pengumpulan ini peneliti sekaligus akan melakukan pengamatan pertama terhadap kumpulan kategorisasi data pemetaan hoaks tersebut. Pengamatan elemen konten tersebut mencakup, tema, saluran, bentuk, tipe.

2. Melakukan analisis isi terhadap kumpulan kategorisasi data pemetaan hoaks. Selanjutnya, data pemetaan hoaks tersebut dianalisa dan dinterpretasi serta diberikan makna.

3. Setelah kategorisasi data pemetaan hoaks dianalisa, peneliti kemudian membuat interpretasi-interpretasi yang dielaborasikan dengan referensi, teori yang dikemukakan Jean Baudillard serta data dari sumber lain yang dapat mendukung sesuai dengan penelitian ini.

4. Setelah seluruh tahap analisis dan pembahasan selesai, peneliti membuat kesimpulan dari hasil analisa terhadap informasi hoaks covid-19 tersebut.

\section{HASIL DAN PEMBAHASAN}

Penelitian ini dilakukan dengan menggunakan data pemetaan informasi hoaks yang diperoleh dari website covid19.go.id dan dihimpun oleh Mafindo. Data-data pemetaan berupa kategorisasi informasi hoaks tersebut dianalisis dengan menggunakan metode analisis isi kualitatif. Analisis isi kualitatif dilakukan dengan memberikan interpretasi dan makna terhadap data pemetaan serta mereduksi data guna menyesuaikan dengan kebutuhan penelitian ini.

Berdasarkan data pemetaan informasi hoaks yang diperoleh melalui observasi dan pengamatan melalui audio visual maka pada masa periode awal pandemik yaitu Januari sampai dengan Agustus 2020 penyebaran hoaks di masyarakat mencapai angka 544 hoaks. Berdasarkan data diatas bila dirata-rata pada masa periode tersebut penyebaran hoaks setiap minggunya mencapai 24 hoaks.

Tabel 1. Tema Hoaks Covid 19

\begin{tabular}{lc}
\hline Tema Hoaks Covid-19 & Persentase \\
\hline Politik & $3 \%$ \\
Agama & $10 \%$ \\
Etnis / Sara & $8 \%$ \\
Kesehatan / Nutrisi & $40 \%$ \\
Bencana & $11 \%$ \\
Lain-lain & $26 \%$ \\
\hline \multicolumn{1}{c}{ TOTAL } & $\mathbf{1 0 0 \%}$ \\
\hline
\end{tabular}

Sumber: Mafindo (2020)

Jumlah rata-rata penyebaran hoaks yang cukup banyak tersebut tentunya tidak didominasi hanya pada satu tema tertentu saja namun pemetaannya mencakup sejumlah tema yaitu politik, agama, etnis atau sara, kesehatan, bencana dan tema lainnya. Tema kesehatan menjadi tema hoaks yang paling banyak diproduksi yaitu mencapai 40 persen. Sedangkan, tema lain-lain menempati urutan kedua yaitu 26 persen, dan berikutnya diikuti oleh tema bencana 11 persen, agama 10 persen, etnis dan sara 8 persen, serta politik 3 persen.

Tabel 2. Saluran Penyebaran Hoaks

\begin{tabular}{lc}
\hline \multicolumn{1}{c}{$\begin{array}{c}\text { Saluran Penyebaran } \\
\text { Hoaks }\end{array}$} & Persentase \\
\hline Facebook & $43 \%$ \\
WhatsApp & $25 \%$ \\
Twitter & $15 \%$ \\
News Online Media & $7 \%$ \\
Instagram & $2 \%$ \\
Lain-lain & $3 \%$ \\
Lebih dari satu saluran & $3 \%$ \\
\hline \multicolumn{2}{c}{ TOTAL } \\
\hline
\end{tabular}

Sumber: Mafindo (2020)

Berdasarkan pada data pemetaan tema hoaks tersebut diatas, untuk penyebaran informasi hoaks itu sendiri secara keseluruhan penyebarannya memanfaatkan berbagai platform teknologi informasi yang terkoneksi dengan internet. Facebook masih merupakan media sosial yang paling tinggi dimanfaatkan sebagai saluran penyebaran hoaks yaitu mencapai 43persen. Aplikasi chating WhatsApp menempati posisi kedua penyebaran hoaks yang mencapai anka 25 persen. Selanjutnya, sekitar 30 persen didominasi oleh berbagai platform seperti twitter 15 persen, media online 7 persen, saluran lain dan yang memanfaatkan lebih dari satu saluran hanya di angka 3 persen. Instagram menjadi media sosial yang terendah dalam penyebaran informasi hoaks yaitu hanye berkisar 2 persen.

Tabel 3. Bentuk Hoaks

\begin{tabular}{lc}
\hline \multicolumn{1}{c}{ Bentuk Hoaks } & Persentase \\
\hline Teks & $32 \%$ \\
Foto & $5 \%$ \\
Video & $11 \%$ \\
Ilustrasi Grafis & $1 \%$ \\
Campuran & $51 \%$ \\
\hline \multicolumn{1}{c}{ TOTAL HOAKS } & $\mathbf{1 0 0 \%}$ \\
\hline
\end{tabular}

Sumber: Mafindo (2020) 
Lebih lanjut, data pemetaan berikutnya dari informasi hoaks terkait dengan bentuk-bentuk hoaks. Berdasarkan data pemetaan tersebut, terdeteksi ada lima bentuk hoaks yang banyak dimanfaatkan oleh para penyebar hoaks, yaitu teks, foto, video dan illustrasi grafis serta campuran. Untuk bentuk campuran merupakan bentuk yang paling banyak digunakan yaitu mencapai persentase sebesar 51 persen. Bentuk hoaks campuran itu sendiri merujuk pada bentuk dengan memanfaatkan berbagai bentuk visual dan teks menjadi satu informasi. Sedangkan, teks merupakan bentuk terbanyak kedua sebesar 32 persen setelah bentuk campuran. Selanjutnya, bentuk audio visual atau video merupakan bentuk ketiga yang paling dimanfaatkan untuk hoaks persentase penggunaan video sebesar 11 persen. Bentuk yang lain untuk visual dua dimensi seperti foto dan illustrasi grafis masing-masing mencapai 5 persen untuk foto, serta illustrasi grafis 1 persen.

Tabel 4. Tipe Hoaks

\begin{tabular}{lcc}
\hline \multicolumn{1}{c}{$\begin{array}{c}\text { Saluran } \\
\text { Penyebaran Hoaks }\end{array}$} & Persentase & Jumlah \\
\hline $\begin{array}{l}\text { Konten yang } \\
\text { Menyesatkan } \\
\text { (Misleading Content) }\end{array}$ & $43.75 \%$ & 238 \\
$\begin{array}{l}\text { Konten Salah } \\
\text { (False Context) }\end{array}$ & $30.70 \%$ & 167 \\
$\begin{array}{l}\text { Konten Palsu } \\
\text { (Fabricated Content) }\end{array}$ & $17.28 \%$ & 94 \\
$\begin{array}{l}\text { Konten yang } \\
\text { Dimanipulasi } \\
\text { (Manipulated }\end{array}$ & $5.88 \%$ & 32 \\
$\begin{array}{l}\text { Content) } \\
\text { Koneksi yang Salah } \\
\text { (False Connection) }\end{array}$ & $1.47 \%$ & 8 \\
$\begin{array}{l}\text { Konten Tiruan } \\
\text { (False Content) }\end{array}$ & $0.92 \%$ & 5 \\
\hline \multicolumn{1}{c}{ TOTAL } & $\mathbf{1 0 0 \%}$ & $\mathbf{5 4 4}$ \\
\hline
\end{tabular}

Sumber: Mafindo (2020)

Berdasarkan pada beberapa pemetaan kategorisasi informasi hoax yang telah dijelaskan sebelumnya, terindikasi beberapa type hoaks yang beredar di masyarakat. Type hoaks tersebut diantaranya adalah konten yang menyesatkan, konten salah, konten palsu, konten yang dimanipulasi, koneksi yang salah dan konten tiruan. Sejumlah type hoaks tersebut merujuk pada pengertian sebagai berikut, konten yang menyesatkan merupakan type informasi sesat yang dengan sengaja untuk membingkai isu yang berkembang atau membingkai individu. Sedangkan, type hoaks konten salah mengacu pada bentuk type hoaks dimana informasi yang asli dihilangkan dan sengaja diganti dengan informasi yang salah. Selanjutnya, untuk type konten palsu merupakan informasi yang seluruhnya salah atau bohong yang sengaja dibentuk dan didesain untuk menipu serta merugikan orang. Untuk konten yang dimanipulasi merupakan type hoaks ketika informasi atau gambar yang asli dimanipulasi sedemikian rupa untuk menipu. Beberapa type yang lain seperti koneksi yang salah merupakan informasi hoaks dimana penulisan judul, penggunaan gambar/visual dan keterangan pendukung tidak sesuai atau tidak mendukung konten dan type terakhir untuk konten tiruan merupakan type hoaks dimana sumber yang asli ditiru.

Terkait dengan peredaran informasi hoaks covid 19, konten yang menyesatkan (misleading content) merupakan type tertinggi yang mencapai 43.75 persen atau berjumlah 238 informasi hoax. Sedangkan, konten salah menjadi type terbanyak kedua sebesar 167 hoaks atau sekitar 30.70 persen. Untuk type terbanyak berikutnya yang marak beredar di masyarakat adalah type konten palsu yaitu sebesar 94 hoaks atau 17.28 persen. Konten yang dimanipulasi tidak terlalu besar dibandingkan dengan tiga type sebelumya yaitu berkisar 5.88 persen atau 32 informasi hoaks. Selanjutnya, untuk koneksi yang salah sebesar 1.47 persen dengan jumlah hoaks tidak lebih dari 10 informasi. Konten tiruan menjadi type yang rendah dengan jumlah persentase hanya 0.92 persen atau berjumlah lima informasi hoaks.

Menurut hasil analisis isi kualitatif yang dilakukan terhadap data pemetaan informasi hoax covid-19 yang beredar pada masa periode awal pandemik yaitu Januari sampai dengan Agustus 2020 menunjukkan bahwa perkembangan teknologi komunikasi memberikan kemudahan bagi siapa pun untuk dapat merancang dan menyebarkan informasi secara mudah. Hal ini ditunjukkan dengan besaran jumlah informasi hoaks yang beredar di masyarakat yang mencapai 544 hoaks atau setara 24 hoaks per minggu. Bahkan, dari jumlah informasi hoaks yang beredar di masyarakat terindikasi sejumlah bentuk atau tipe hoaks yang berbeda-beda. Berbagai macam type hoaks ini tentunya memperlihatkan bahwa produsen konten hoaks tidak saja sekedar memproduksi satu informasi hoaks tertentu, namun didalamnya ada aspek "kreasi" yang dilakukan dengan menggunakan berbagai multimedia seperti bentuk teks, visual, maupun audio visual. Aspek "kreasi" tersebut bisa dilakukan, karena perkembangan teknologi yang pesat saat ini memungkinkan untuk melakukan hal tersebut.

Selain itu, kemudahan yang ditawarkan melalui teknologi informasi tidak saja dimanfaatkan dalam 
hal merancang dan membentuk konten hoaks dengan menggunakan berbagai macam bentuk multimedia, namun juga memberikan kemudahan untuk melakukan penyebaran hoaks secara lebih massif. Kemudahan tersebut dilakukan dengan memanfaatkan berbagai platform media sebagai saluran untuk mendistribusikannya, seperti media sosial maupun aplikasi percakapan atau chating. Melalui berbagai platform saluran yang dijembatani dengan teknologi internet itulah para produsen hoaks dan masyarakat berinteraksi, saling mengirimkan dan menerima pesan. Masyarakat dibanjiri dengan berbagai informasi tentang berbagai hal termasuk informasi covid 19 yang tidak seluruhnya benar.

Berdasarkan perspektif Baudillard hal tersebut menunjukkan bahwa pada dasarnya penggunaan teknologi informasi yang berkembang pesat saat ini, manusia telah membuka realitas dunia yang semu bagi dirinya sendiri. Melalui teknologi yang serba digital saat ini manusia gemar untuk memproduksi berbagai macam simulasi dalam kehidupannya. Penggunaan teknologi oleh masyarakat merubah perilaku dan kebiasaan masyarakat itu sendiri. Bahkan, dalam kondisi krisis pandemik covid 19 saat ini, manusia kehilangan akal sehatnya dan rela menjerumuskan manusia lain ke dalam kekalutan dengan menyebarkan informasi yang menyesatkan. Sehingga, akibat dari perbuatannya tersebut manusia menjadi sulit untuk membedakan mana yang benar dan salah.

Selain itu, tindakan lain yang sering dilakukan oleh masyarakat saat ini dengan menggunakan teknologi adalah kecenderungan untuk memanipulasi diri. Bentuk manipulasi yang kerap dilakukan salah satunya adalah membuat profil media sosial palsu dengan memanfaatkan berbagai macam foto, video dan menggunakan informasi identitas milik orang lain. Tindakan yang kerap disebut dengan catfishing tersebut memiliki tujuan-tujuan tertentu seperti untuk perundungan siber, menyebarkan hoaks atau mencari perhatian dengan memanfaatkan teknologi. Hal inilah salah satu implikasi dari konsep simulacra yang dikemukakan oleh Baudillard yaitu hilangnya nilai-nilai moral dalam diri manusia.

Pada level ini, Baudillard melihat hal tersebut akibat dari terpaan berbagai konten media yang disalurkan melalui berbagai platform, manusia menjadi terpaku dengan berbagai kebutuhan konsumerisme. Konsumerisme yang dimaksud oleh Baudillard disini, masyarakat tidak lagi mengacu pada nilai guna dan nilai pakai, tetapi lebih kepada nilai simbol (Redana,et.al. 1997:181) Sehingga, pada akhirnya yang tampak pada level tersebut adalah citra atau image menjadi point penting dan utama bagi masyarakat saat ini. Hal ini termasuk merujuk pada kebutuhan informasi itu sendiri, dimana informasi tidak hanya dipergunakan sebagai alat dagang tetapi telah menjadi produk utama.

Bila dikaitkan dengan hoaks covid 19 maka hal ini tampak pada fenomena peredaran hoaks dimana masyarakat cenderung ingin dipandang sebagai seseorang yang unggul dari yang lain. Rasa bangga dan senang muncul jika menjadi seseorang yang merasa pertama kali menyebarkan informasi dikondisi krisis. Sedangkan, dari sisi produsen atau perancang hoaks merasa menjadi seseorang yang unggul karena berani menentang dan mengekspresikan ketidakpuasannya terhadap pemerintah seorang diri melalui akun media sosial yang dimilikinya. Baudillard menyatakan hal tersebut dengan realitas semu manusia, bahwa masyarakat kontemporer saat ini sangat dipengaruhi oleh digitalisasi, jaringan internet, ruang virtual atau realits simulacra. Berbagai macam informasi yang tersebar di internet terutama media sosial mampu mempengaruhi masyarakat maupun individu, bahkan hal tersebut mampu merubah pandangan seseorang, seperti membenci individu maupun institusi.

\section{KESIMPULAN}

Berdasarkan pada hasil penelitian dan pembahasan diatas maka perkembangan teknologi komunikasi telah merubah produksi utama manusia modern. Jika dulu produksi utama manusia adalah barang-barang yang sifatnya dapat direplikasi, seperti mobil, traktor dan alat-alat pertanian, saat ini produksi utama manusia adalah informasi. Informasi sebagai produk utama masyarakat informasi tidak lagi didominasi oleh produsen informasi seperti stasiun televisi dan surat kabar, namun saat ini siapa pun yang memiliki gawai dan terkoneksi dengan internet dapat memproduksi informasi dan membagikannya melalaui berbagai aplikasi yang tersedia.

Dampak dari hal tersebut manusia terjebak dalam realitas semu dan berkutat pada duplikasi, kedangkalan dan kepura-puraan semata. Hal tersebut berpengaruh pada perilaku masyarakat yang pada akhirnya menyebabkan hilangnya moral dalam masyarakat itu sendiri. Bahkan, dalam kondisi kritis pandemi covid 19 masyarakat cenderung memanfaatkan situasi ini dengan mengkomodifikasinya menjadi nilai yang ditujukan untuk kepentingan-kepentingan pribadi, politik maupun kelompok.

\section{REFERENSI}

Bungin, M. Burhan. (2007). Penelitian Kualitatif: Komunikasi, Ekonomi, Kebijakan Publik, dan Ilmu Sosial Lainnya. Jakarta:Kencana Prenada Media.

Edkins, Jenny, et.al. (2010). Teori-teori Kritis: Menantang Pandangan Utama Studi 
Politik Internasional. Yogyakarta: Baca!,

Kadir, Abdul. (2002). Pengenalan Sistem Informasi. Yogyakarta:Andi.

Kaufmann, Vincent. (2006). The Lessons of Guy Debord, October Magazine, Ltd and Massachusetts Institute of Technology, United States of America.

Kriyantono, Rachmat. (2012).Teknik Praktis Riset Komunikasi. Jakarta:Kencana.

Lubis, Akhyar Yusuf. (2014). Postmodernisme: Teori dan Metode. Jakarta: Rajawali Pers.

McFadden, et.al. (1999). Konsep dan tuntunan Praktis Basis Data. Yogyakarta: Andi.

Redana, Bre, et.al.(1997). Ecstasy Gaya Hidup. Bandung:Mizan,

Schreier, Margrit, (2012). Qualitative Content Analysis in Practice. London: Sage Publications.

Silverman, Craig.(2015). Journalism: A Tow/Knight Report."Lies, Damn Lies,

and Viral Content". Columbia Journalism Review

Sugiyono.(2017). Metode Penelitian Kualitatif. Bandung: Alfabeta.

Wahyuni, Hermin Indah.(2020). Keriuhann Komunikasi. Jakarta: Yayasan Pustaka Obor Indonesia.

https://databoks.katadata.co.id/datapublish/2019/06/ 14/survei-cigi-facebook-medsos-yang-banyakdigunakan-untuk-menyebar-hoaks, diakses Rabu 22 Juli 2020, Jam 14.43

https://www.liputan6.com/news/read/3867707/hoax -adalah-ciri-ciri-dan-cara-mengatasinya-di-duniamaya-dengan-mudah, diakses Senin 6 Juli 2020, jam 15.46

https://www.beritasatu.com/digital/645413-137829hoax-covid19-teridentifikasi-gugus-tugas, diakses Rabu 8 Juli 2020, jam 12.33 .

https://health.grid.id/read/352060470/wabah-viruscorona-covid-19-mengancam-kesehatan-mentaljuga-akibat-banyaknya-berita-hoax?page=all, diakses Rabu 8 Juli 2020, jam 14.03

https://health.grid.id/read/352060470/wabah-viruscorona-covid-19-mengancam-kesehatan-mentaljuga-akibat-banyaknya-berita-hoax?page=all, diakses Jumat 24 Juli 2020, jam 13.44

https://www.pikiran-rakyat.com/nasional/pr01377073/selama-pandemi-covid-19-jumlah-kasushoaks-alami-peningkatan?page $=2$, diakses Jumat 17 Juli 2020, jam 15.42 https://databoks.katadata.co.id/datapublish/2020/02/

26/indonesia-habiskan-hampir-8-jam-untuk-

berinternet, diakses Rabu 1 Juli 2020, jam. 14.38.

https://www.who.int/news/item/23-09-2020-

managing-the-covid-19-infodemic-promotinghealthy-behaviours-and-mitigating-the-harm-frommisinformation-and-disinformation, diakses Rabu 6 Januari 2021, jam 05.41.

https://www.who.int/news-room/spotlight/let-sflatten-the-infodemic-curve, diakses Rabu 6 Januari 2021, jam 05.47.

https://kominfo.go.id/content/detail/25895/ancaman -infodemik-dapat-memperburuk-

pandemicovid19/0/virus_corona\#: :text=Infodemik $\% 20$ ini\%20mengarah\%20pada\%20informasi,penca rian\%20solusi\%20terhadap \%20masalah\%20tersebu t. diakses Rabu 5 Januari 2021, jam 04.30.

https://www.google.com/amp/s/amp.kompas.com/tr en/read/2020/09/27/090000665/studi--infodemikpaling-banyak-di-6-negara-termasuk-indonesia, diakses Rabu 5 Januari 2021, jam 04.40

http://www.ajtmh.org/content/journals/10.4269/ajt mh.20-0812, diakses Rabu 5 Januari 2021, jam 04.52

https://theconversation.com/apa-bedanya-pandemiepidemi-dan-wabah-133491.

https://www.who.int/news/item/23-09-2020managing-the-covid-19-infodemic-promotinghealthy-behaviours-and-mitigating-the-harm-frommisinformation-and-disinformation, diakses Rabu 6 Januari 2021, jam 05.41.

https://www.who.int/news-room/spotlight/let-sflatten-the-infodemic-curve, diakses Rabu 6 Januari 2021, jam 05.47.

https://kominfo.go.id/content/detail/25895/ancaman -infodemik-dapat-memperburu 

pandemiovid19/0/virus_corona\#: :text=Infodemik\% 20ini\%20mengarah\%20pada\%20informasi,pencarian $\% 20$ solusi\%20terhadap\%20masalah\%20tersebut, diakses Rabu 5 Januari 2021, jam 04.30.

https://www.google.com/amp/s/amp.kompas.com/tre n/read/2020/09/27/090000665/studi--infodemikpaling-banyak-di-6-negara-termasuk-indonesia, diakses Rabu 5 Januari 2021, jam 04.40

http://www.ajtmh.org/content/journals/10.4269/ajtmh .20-0812, diakses Rabu 5 Januari 2021, jam 04.52

https://interaktif.kompas.id/baca/bahaya-infodemik/, diakses Jumat 8 Januari 2021, jam 04.13.

https://www.bulelengkab.go.id/detail/artikel/pengerti an-hoax-dan-ciri-cirinya-

41 ?fb comment id=1873715239403533 195460199 7981523, diakses Jumat 8 Januari 2021, jam 19.41. https://www.kompas.com/tren/read/2020/03/18/1305 30565/gugus-tugas-luncurkan-covid19goid-apa-sajaisinya? page $=$ all, diakses Jumat 8 Januari 2021, jam 20.26 .

https://www.mafindo.or.id/wpcontent/uploads/2020/11/Executive-

Summary_General-Hoax-Mapping-Semester-12020.pdf, diakses desember 2020, jam 12.00

\section{PROFIL PENULIS}

\section{Ignasius Liliek Senaharjanta}

Lahir di Jakarta, 20 November 1979, saat ini aktif sebagai dosen tetap Ilmu Komunikasi di Fakultas Ilmu Sosial dan Humaniora, Universitas Bunda Mulia dengan fokus kajian pada media studies, komunikasi visual dan politik.

\section{Shella Fendista}

Lahir di Jakarta, 20 September 1998, saat ini sedang menempuh pendidikan Sarjana Ilmu Komunikasi di Universitas Bunda Mulia dan sedang dalam proses menyelesaikan tugas akhir skrips. Penulis dapat dihubungi melalui email: shellafendista@gmail.com 